\title{
Hormonal Actions and Interactions in Proximal Tubule Cells Associated with the Development of Chronic Kidney Disease
}

\author{
Akihiko Saito ${ }^{1}$, Michihiro Hosojima ${ }^{2}$ and Hiroyoshi Sato ${ }^{1}$ \\ ${ }^{1}$ Department of Applied Molecular Medicine \\ ${ }^{2}$ Division of Clinical Nephrology and Rheumatology \\ Niigata University Graduate School of Medical and Dental Sciences
}

Japan

\section{Introduction}

As the first tubular segment of the kidney between the Bowman's capsule and the loop of Henle, the proximal tubule is exposed to initial glomerular filtrates. Proximal tubule cells (PTCs) have a variety of functions including 1) reabsorption and intracellular processing of glomerular-filtered substances such as proteins, peptides, glucose, amino acids, uric acid, sodium, potassium, phosphate, bicarbonate and water via apical membrane receptors, transporters, and channels; 2) uptake of substances such as protein-bound compounds via basolateral membrane transporters, followed by metabolism or secretion to the urinary space; and 3) synthesis of bioactive substances that are released to peritubular capillaries (Fig. 1).

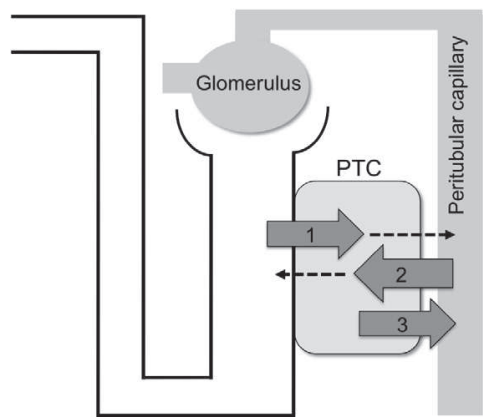

Normal functions of PTCs (indicated by arrows) include: 1) reabsorption and intracellular processing of glomerular-filtered substances via apical membrane receptors, transporters, and channels; 2 ) uptake of substances via basolateral membrane transporters followed by metabolism or secretion into the urinary space; and 3) synthesis of bioactive substances that are released to peritubular capillaries.

Fig. 1. Normal functions of proximal tubule cells (PTCs)

Impairment of these diverse functions is likely to affect systemic hemodynamic and metabolic homeostasis and can lead to the development of chronic kidney disease (CKD) and cardiovascular disease (CVD) (Saito, Kaseda et al. 2010). In particular, PTC injury occurs during the early stages of diabetic nephropathy, a leading cause of CKD. 
In this review, we focus on actions and interactions of various hormones and hormone-like substances on the regulation of apical membrane receptors and transporters that mediate three major functions of PTCs: 1) receptor-mediated protein endocytosis, 2) sodium reabsorption, and 3) phosphate reabsorption, which are particularly associated with the pathophysiology of CKD and the increased risk of CVD (Fig. 2).

\section{Hormonal actions and interactions for regulating protein endocytosis in PTCs}

Receptor-mediated endocytosis is a pivotal function of PTCs through which the cells reabsorb and metabolize proteins (and other substances) from glomerular filtrates (Saito, Sato et al. 2010). This reabsorption process is extremely efficient as urine is virtually proteinfree in humans, and it accounts for the essential conservation of nutrients, carrier-bound vitamins, and trace elements filtered by glomeruli. Impairment of the process results in a loss of such substances and development of proteinuria.

\subsection{Endocytic receptors involved in protein reabsorption in PTCs}

The two major endocytic receptors expressed at the apical membranes of PTCs are megalin and cubilin (Saito, Sato et al. 2010) which act cooperatively in the uptake of glomerularfiltered proteins and mediate their metabolism in PTCs (Fig. 2).

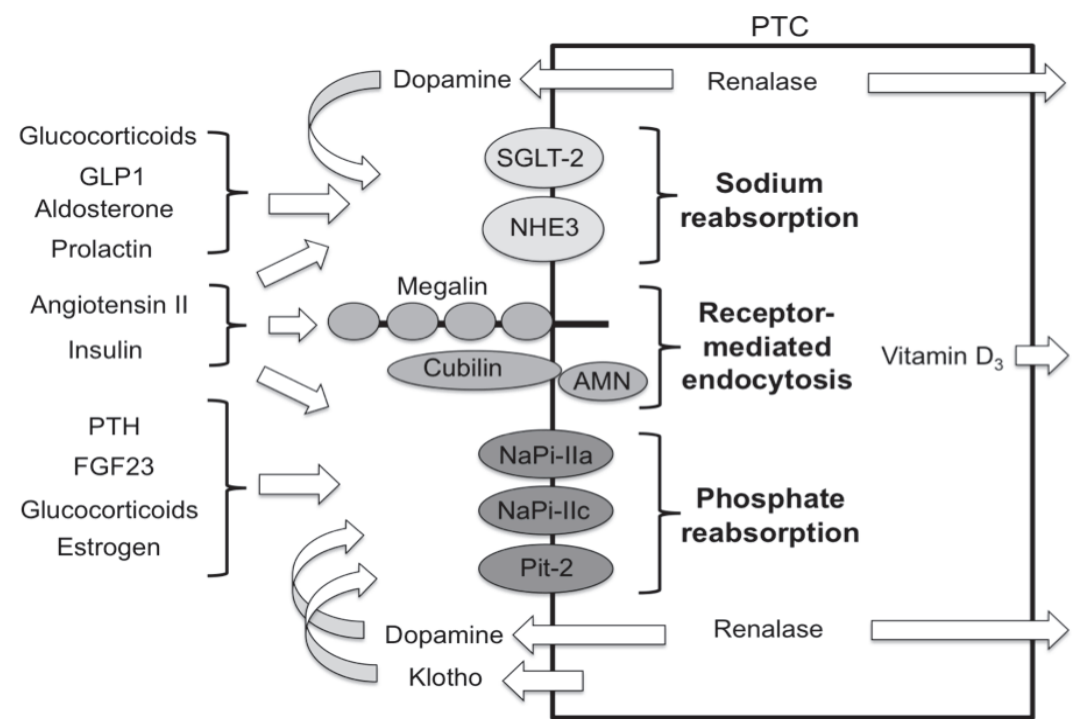

Some hormones, such as dopamine, renalase, vitamin D3 and klotho, are synthesized in PTCs and others come from other organs. Renalase acts to metabolize dopamine.

AMN, amnionless; FGF23, fibroblast growth factor 23; GLP1, glucagon-like peptide 1; NaPi-IIa, sodiumdependent phosphate cotransporter type IIa; NaPi-IIc, sodium-dependent phosphate cotransporter type IIc; NHE3, $\mathrm{Na}^{+} / \mathrm{H}^{+}$exchanger isoform 3; Pit-2, sodium-dependent phosphate symporter 2; PTC, proximal tubule cell; PTH, parathormone; SGLT2, sodium-glucose cotransporter 2

Fig. 2. Hormonal actions and interactions on the functions of receptors and transporters involved in receptor-mediated protein endocytosis and reabsorption of sodium and phosphate in the apical membrane of PTCs. 


\subsubsection{Megalin}

Megalin is a large $(\sim 600 \mathrm{kDa})$ glycoprotein member of the low-density lipoprotein receptor family that is primarily expressed in clathrin-coated pits (Saito, Sato et al. 2010). Megalinligand complexes are internalized by invagination of clathrin-coated pits mediated by multiple adaptor proteins and motor molecules, forming endosomal vesicles. Acidification of the intravesicular lumen dissociates the ligands from megalin and they are transported to lysosomes for degradation or storage or are secreted into the cytosol for further processing or transport. Megalin is then recycled to the apical membranes through a recycling compartment. Megalin thus plays a critical role in reabsorption and metabolism of glomerular-filtered substances including albumin and low molecular weight proteins. Vitamin D-binding protein (DBP) is an endocytic ligand of megalin, and megalin knockout mice display decreased utilization of vitamin D for its activation in PTCs (Nykjaer et al. 1999; Leheste et al. 2003) (Fig. 3).

Decreased megalin expression in PTCs has been observed in the early diabetic stages of experimental animals (Tojo et al. 2001; Russo et al. 2007), and it has been suggested that the functions of megalin are also impaired in patients during the early stages of diabetic nephropathy, since low molecular weight proteinuria is frequently observed in patients at these stages (Pontuch et al. 1992; Hong et al. 2003). Therefore, the altered regulation of megalin expression and its functions must be primarily responsible for the early development of proteinuria/albuminuria in diabetic patients.

Megalin also interacts with various membrane receptors and transporters such as the cubilin/amnionless complex, sodium-hydrogen exchanger isoform 3 (NHE3) and sodiumdependent phosphate cotransporter type IIa (NaPi-IIa) as discussed in the following sections.

\subsubsection{Cubilin}

Cubilin is a $460-\mathrm{kDa}$ peripheral glycoprotein that lacks transmembrane and intracellular segments but is anchored to apical PTC membranes. It was originally identified as the receptor for intrinsic factor-vitamin $B_{12}$ complex (Seetharam et al. 1988; Seetharam et al. 1997). Cubilin requires interaction with megalin to regulate its endocytic functions (Yammani, Seetharam, and Seetharam 2001; Kozyraki et al. 2001); however, it is bound more firmly by a protein called amnionless forming the complex CUBAM (Fyfe et al. 2004; Coudroy et al. 2005). Cubilin gene defects are the cause of hereditary megaloblastic anaemia 1 and Imerslund-Gräsbeck syndrome, also known as selective vitamin $B_{12}$ malabsorption with proteinuria (Aminoff et al. 1999). Cubilin is also involved in the absorption of various protein ligands present in glomerular filtrates, including albumin, transferrin and DBP (Christensen, Verroust, and Nielsen 2009). A recent meta-analysis of genome-wide association studies identified a missense cubilin gene variant associated with levels of albuminuria in both the general population and in diabetic individuals (Boger et al. 2011).

\subsubsection{Amnionless}

Amnionless is a $38-50 \mathrm{kDa}$ membrane protein with a single transmembrane domain that was initially identified as a component required for normal development of the trunk mesoderm derived from the middle streak (Kalantry et al. 2001). In addition, defects of the amnionless gene cause hereditary megaloblastic anaemia (Tanner et al. 2003). 


\subsection{Hormones regulating the expression and function of endocytic receptors}

Angiotensin II and insulin are two major hormones involved in regulating the expression and function of megalin (Hosojima et al. 2009) (Fig. 2), but no hormones have been identified that regulate cubilin and amnionless expression.

\subsubsection{Angiotensin II}

Angiotensin II downregulates the expression and function of megalin via the extracellularsignal-regulated kinase (ERK)1/2 signaling pathway in cultured PTCs (Hosojima et al. 2009). Intrarenal levels of angiotensin II are augmented in CKD (Kobori et al. 2007), which is involved in the development of hypertension as discussed below. Angiotensin-converting enzyme inhibitors and angiotensin II receptor blockers are thus likely to target the increased action of angiotensin II in the kidney. These agents may be effective in suppressing the reduced expression of megalin in CKD and in preventing proteinuria/albuminuria (Tojo et al. 2003).

Megalin also appears to regulate the intrarenal actions of angiotensin II by internalizing angiotensin II (Gonzalez-Villalobos et al. 2005) and angiotensin-(1-7) (Gonzalez-Villalobos et al. 2006), as well as mediating the endocytosis of angiotensinogen that is filtered by glomeruli (Pohl et al. 2010).

\subsubsection{Insulin}

Insulin is involved in the upregulation of megalin, which in turn may be associated with increased endocytosis and metabolism of glomerular-filtered proteins, leading to intracellular metabolic overload. Cross-talk between insulin-insulin receptor substrate/phosphoinositide 3-kinase and angiotensin II-ERK1/2 signaling pathways was previously observed in cultured PTCs (Hosojima et al. 2009), and the balance between the actions and interactions of angiotensin II and insulin may also be important in regulating the expression of megalin in vivo. Hyperinsulinemia associated with metabolic syndrome is thought to stimulate insulin signaling in PTCs, while impaired insulin signaling (so-called insulin resistance) is suggested to occur in kidney cells in type 2 diabetic models; moreover, the intrarenal activation of angiotensin II appears to be associated with the development of insulin resistance (Tiwari et al. 2007). Recently, megalin was shown to be downregulated by the lipopolysaccharide-tumor necrosis factor$\alpha$-ERK1/2 signaling pathway that may also impair insulin signaling in diabetes (Takeyama et al. 2011). In addition, positive control of megalin expression has been demonstrated by peroxisome proliferator-activated receptor isoforms peroxisome proliferator-activated receptor (PPAR) $\alpha$ and PPAR $\gamma$ and their insulin-sensitizing agonists (Cabezas et al. 2011).

\section{Hormonal actions and interactions for regulating sodium reabsorption in PTCs}

Sodium reabsorption from glomerular filtrates is an important function of PTCs in the maintenance of systemic hemodynamics. Impairment of this function is associated with the abnormal regulation of blood pressure, especially in patients with CKD. Moreover, increased PTC sodium reabsorption causes glomerular hyperfiltration via the tubuloglomerular feedback mechanism, particularly in diabetes (Thomson, Vallon, and Blantz 2004). 


\subsection{Major transporters involved in sodium reabsorption and regulated by hormones in PTCs}

Various transporters and channels are involved in sodium reabsorption in the apical and basolateral membranes of PTCs. Here, we focus on three types of apical transporters (Fig. 2).

\subsubsection{Sodium-hydrogen exchanger isoform 3}

Sodium-hydrogen exchanger isoform 3 (NHE3), the main NHE isoform of PTCs, mediates isotonic reabsorption of approximately two-thirds of filtered $\mathrm{NaCl}$ and water, the reabsorption of bicarbonate, and the secretion of ammonium (Bobulescu and Moe 2009). It also contributes to the reabsorption of filtered citrate, amino acids, and oligopeptides by providing $\mathrm{H}^{+}$used by $\mathrm{H}^{+}$-coupled cotransporters. Indeed, enhanced NHE3 activity is assumed to be a factor for the increased sodium reabsorption and the development of hypertension in diabetes. NHE3 was reported to interact with megalin in PTC intermicrovillar clefts (Biemesderfer et al. 1999; Biemesderfer, DeGray, and Aronson 2001) and, following endocytosis with megalin, it is postulated to utilize the outward transvesicular sodium gradient of endocytic vesicles and early endosomes to drive the inward movement of $\mathrm{H}^{+}$and endosomal acidification. This is important for dissociating reabsorbed ligand proteins from megalin both for further processing and megalin recycling to the cell surface. Hormonal regulation of NHE3 has been intensively investigated and reviewed elsewhere (Bobulescu and Moe 2009).

\subsubsection{Sodium-glucose cotransporter-2}

Glucose is freely filtered by glomeruli before being almost entirely reabsorbed into the circulation from PTCs. Reabsorption of the majority of glucose is achieved by sodiumglucose cotransporter-2 (SGLT2), which is present in the S1 segment of proximal tubules. Expression of SGLT2 is enhanced in the kidney of diabetic Zucker rats (Tabatabai et al. 2009). SGLT2 inhibitors currently in development are expected not only to treat hyperglycemia but also to have an effect on hypertension and glomerular hyperfiltration in diabetic patients (Bailey et al. 2010; List and Whaley 2011).

\subsubsection{Sodium-dependent phosphate cotransporters}

Sodium-dependent phosphate cotransporters reabsorb inorganic phosphate in a sodiumdependent manner in PTCs. These will be discussed in detail in section 4.1.

\subsection{Hormones regulating the expression and function of the transporters involved in sodium reabsorption in PTCs}

Many hormones are involved in the regulation of sodium reabsorption in PTCs, particularly through the function of NHE3 (Fig. 2).

\subsubsection{Angiotensin II}

Angiotensin II is important for increasing sodium uptake by PTCs. Intrarenal levels of angiotensin II are augmented in CKD and are also involved in the development of hypertension (Kobori et al. 2007; Navar et al. 2011). The action of angiotensin II on NHE3 has been intensively investigated, indicating biphagic dosage-dependent acute effects and chronic stimulatory effects on NHE3 (Bobulescu and Moe 2009). Classically, angiotensin II has been thought to act on its specific receptors in PTC plasma membranes by endocrine 
and local tissue paracrine mechanisms. However, more recently it was also shown to function in an autocrine or intracrine manner (Li et al. 2011).

\subsubsection{Insulin}

Insulin is an important hormone that regulates sodium uptake as well as glucose metabolism in PTCs. In patients with metabolic syndrome, serum levels of insulin are elevated by a mechanism of insulin resistance in the liver and skeletal muscles. Increased levels of insulin are likely to augment sodium uptake in PTCs (Baum 1987) as well as other nephron segments such as thick ascending limbs (Mandon et al. 1993) and collecting ducts (Takahashi, Ito, and Abe 1996), causing extracellular fluid expansion and hypertension. Insulin has been shown to acutely and chronically stimulate the function of NHE3 in cultured PTCs (Fuster et al. 2007), and its infusion is associated with increased blood pressure in rats (Brands et al. 1991) and humans (Gans et al. 1991).

Diabetic kidneys, however, have been demonstrated to have impaired expression of renal insulin receptors (Tiwari et al. 2007). In kidney-specific insulin receptor KO mice, basal systolic blood pressure was increased and natriuresis was reduced in response to a volume load (Tiwari et al. 2008). The greatest relative reduction of the insulin receptor in these mice was found in the thick ascending limb and collecting duct, and renal production of NO was likely to be reduced. A previously uncharacterized role of the insulin receptor in these nephron segments may thus be associated with sodium and water reabsorption via NO production.

\subsubsection{Glucocorticoids}

Glucocorticoids, whether endogenous, as in Cushing syndrome, or exogenous, via pharmacologic provision, induce hypertension (Mangos et al. 2003). They directly stimulate NHE3 through both acute and chronic mechanisms (Bobulescu and Moe 2009). The acute effect of glucocorticoids on cell surface NHE3 is mediated by the activation of HNE3 exocytosis (Bobulescu et al. 2005) and a glucocorticoid receptor-dependent mechanism that activates serum and glucocorticoid-inducible kinase1 (SGK1) in a nongenomic manner (Wang et al. 2007). Glucocorticoids have also been found to enhance the function of insulin in stimulating NHE3 activity (Klisic et al. 2002).

\subsubsection{Glucagon-like peptide 1}

Glucagon-like peptide 1 (GLP1) receptors are expressed in pancreatic cells and other cells such as PTCs (Schlatter et al. 2007). Administration of recombinant GLP1 to Dahl saltsensitive rats resulted in an antihypertensive effect, due mainly to its diuretic and natriuretic actions (Yu et al. 2003). GLP1 was also found to induce natriuresis in healthy subjects and insulin-resistant obese men through its action on PTCs (Gutzwiller et al. 2004). Hyperglomerular filtration in obese men was improved following this treatment, which was likely to be mediated by tubuloglomerular feedback mechanisms.

GLP1 receptor agonistic agents have been used in the treatment of hyperglycemia by acting on GLP1 receptors in pancreatic ß-cells to stimulate insulin synthesis. The GLP1 receptor agonist exendin-4 also decreases sodium reabsorption in PTCs by affecting NHE3 activity (Carraro-Lacroix, Malnic, and Girardi 2009) and reduces blood pressure in a salt-sensitive hypertension mice model (Hirata et al. 2009). Such agents are also suggested to be clinically relevant in reducing blood pressure (Vilsboll et al. 2007; Klonoff et al. 2008). 


\subsubsection{Aldosterone}

Aldosterone stimulates the activity and surface expression of NHE3 in human primary PTCs, which is inhibited by the mineralocorticoid receptor blocker spironolactone and by the epidermal growth factor receptor (EGFR)-kinase inhibitor (Drumm et al. 2006). Aldosterone was found to regulate NHE3 by a nongenomic mechanism (Good, George, and Watts 2006). Aldosterone/mineralocorticoid receptor stimulation is also known to affect PTCs by inducing cellular senescence (Fan et al. 2011), suggesting that it is a potential therapeutic target in CKD.

\subsubsection{Prolactin, dopamine and renalase}

Prolactin is also a natiriuretic hormone that inhibits $\mathrm{Na}^{+}, \mathrm{K}^{+}$, ATPase activity in PTCs, depending on the renal dopamine system (Ibarra et al. 2005). Dopamine is known to both acutely and chronically inhibit the function of NHE3 by reducing its cellular expression (Bobulescu and Moe 2009). Renalase, a secreted amine oxidase that is synthesized in the kidney, metabolizes circulating catecholamines (Xu et al. 2005). Urinary renalase metabolizes urinary catecholamines, and perhaps regulates dopamine concentration in luminal fluid, and modulate the function of NHE3 for proximal tubular sodium transport (Desir 2011).

\section{Hormonal actions and interactions for regulating phosphate reabsorption in PTCs}

Phosphate uptake is an important function of PTCs which is regulated by the actions and interactions of various hormones and hormone-like substances, such as parathormone (PTH), fibroblast growth factor 23 (FGF23), klotho, glucocorticoids, vitamin $\mathrm{D}_{3}$, dopamine and so on (Figs. 2 and 3). Phosphate regulation is particularly associated with the development of cardiovascular disease and high mortality in patients with CKD, independently of the glomerular filtration rate (Kestenbaum et al. 2005). Therefore, the regulation of phosphate uptake in PTCs is clinically important.

\subsection{Transporters involved in PTC phosphate reabsorption that is hormonally regulated}

At least three types of sodium-dependent phosphate transporters have been identified in the brush border membrane of PTCs: NaPi-IIa, NaPi-IIc, and sodium-dependent phosphate symporter 2 (Pit-2) (Fig. 2). Renal reabsorption of inorganic phosphate is mainly (about 70\%) mediated by NaPi-IIa in the adult kidney (Ohkido et al. 2003).

\subsubsection{NaPi-Ila}

$\mathrm{NaPi}$-IIa is a major phosphate transporter of PTCs, and changes in renal phosphate handling are primarily attributable to altered NaPi-Ila brush border membrane expression (Hernando et al. 2005). NaPi-IIa is expressed in the S1-S3 segment of superficial and juxtamedullary nephrons (Picard et al. 2010) and mediates the electrogenic transport of inorganic phosphate coupled to three sodium ions (Murer, Forster, and Biber 2004). NaPi-IIa is regulated by several hormones and other factors, as described in section 4.2. Adequate steady-state expression of $\mathrm{NaPi}-\mathrm{Il} a$ and its inactivation by endocytosis and intracellular translocation require the presence of megalin (Bachmann et al. 2004), such that megalin dysfunction is likely to impair $\mathrm{NaPi}$-IIa inactivation, inducing the increased reabsorption of phosphate (Fig. 3). 


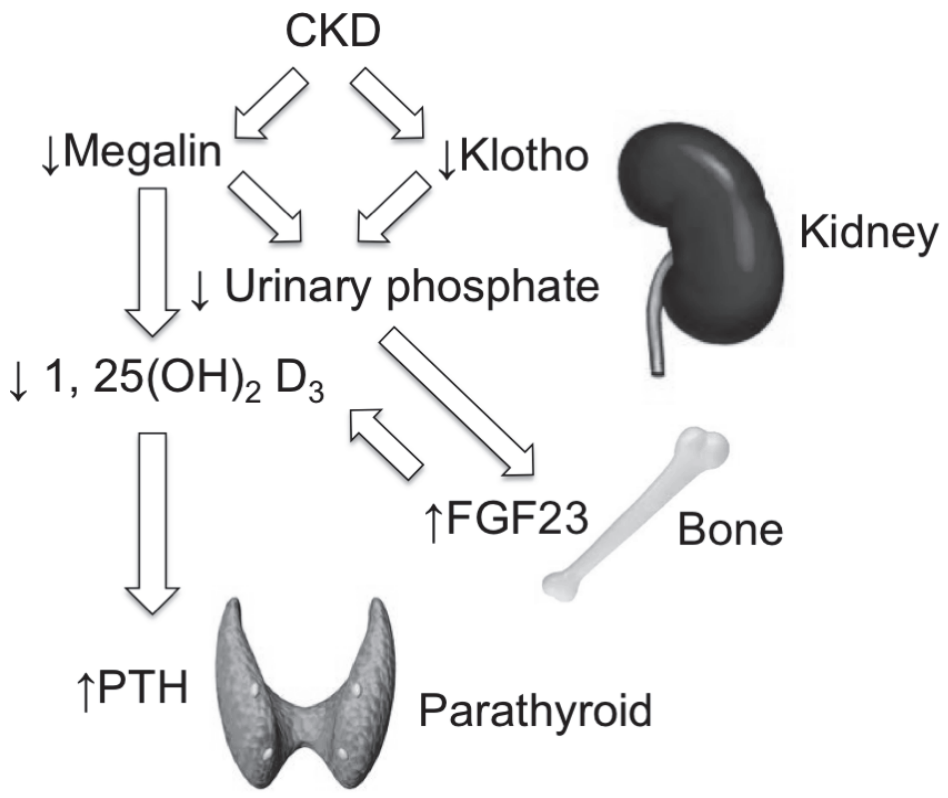

In CKD, renal expression of megalin and klotho is decreased, resulting in increased urinary phosphate excretion. Decreased megalin expression also causes decreased renal synthesis of $1,25(\mathrm{OH})_{2} \mathrm{D}_{3}$.

Synthesis of FGF23 in the bone is then stimulated, which also suppresses renal 1,25(OH $)_{2} \mathrm{D}_{3}$ synthesis, increasing the synthesis of PTH in the parathyroid.

Fig. 3. Presumed hormonal network involved in phosphate regulation in CKD

\subsubsection{NaPi-Ilc}

$\mathrm{NaPi}$-IIc is a growth-related transporter that is more active in the young and has a reduced role in adults (Segawa et al. 2002). NaPi-IIc transports inorganic phosphate in an electroneutral fashion and is highly $\mathrm{pH}$ dependent, exhibiting more transport at a more alkaline $\mathrm{pH}$ (Segawa et al. 2002). It is expressed in the S1 segment of PTCs (Picard et al. 2010) and mutations of the NaPi-IIc gene were found to cause hereditary hypophosphatemic rickets with hypercalciuria $(\mathrm{HHRH})$, a Mendelian disorder of renal inorganic phosphate reabsorption (Bergwitz et al. 2006; Lorenz-Depiereux et al. 2006).

\subsubsection{Pit-2}

Pit-2, expressed in S1 and weakly in S2 segments of superficial and juxtamedullary nephrons (Picard et al. 2010), mediates the electrogenic transport of inorganic phosphate (Ravera et al. 2007).

\subsection{Hormones regulating the expression and function of PTC transporters involved in phosphate reabsorption}

Several hormones and hormone-like substances are involved in the regulation of phosphate cotransporters. In particular, the actions and interactions of PTH, fibroblast growth factor 23 (FGF23), klotho and vitamin $\mathrm{D}_{3}$ are important in maintaining phosphate homeostasis and the development of CKD-mineral bone disease (MBD) (Fig. 2 and 3). 


\subsubsection{PTH}

PTH was first identified as an inactivator of NaPi-IIa through endocytic retrieval and degradation (Bacic et al. 2006). It was then found to be also associated with the endocytic regulation of NaPi-IIc (Segawa et al. 2007), although its acute effects differentially regulate these cotransporters including Pit-2 (Picard et al. 2010). The synthesis of PTH is increased in the progression of secondary hyperparathyroidism in CKD.

\subsubsection{FGF23}

FGF23 is a 32-kDa protein that is secreted mainly by bone osteocytes (Liu et al. 2006). Administration of FGF23 to mice decreases the renal expression of both NaPi-IIa and NaPiIIc and induces hypophosphatemia predominantly via FGF receptor 1 (Gattineni et al. 2009). FGF23 also suppresses $1,25(\mathrm{OH})_{2} \mathrm{D}_{3}$ by inhibiting $1 \alpha$-hydroxylase (CYP27B1), which converts 25-hydroxyvitamin $\mathrm{D}_{3}\left[25(\mathrm{OH}) \mathrm{D}_{3}\right]$ to $1,25(\mathrm{OH})_{2} \mathrm{D}_{3}$, and by stimulating 24hydroxylase (CYP24), which converts $1,25(\mathrm{OH})_{2} \mathrm{D}_{3}$ to inactive metabolites in PTCs (Shimada et al. 2004). Increased FGF23 appears to play a causative role in the abnormal renal phosphate handling and vitamin $\mathrm{D}_{3}$ metabolism of rats with $\mathrm{CKD}$, leading to the development of secondary hyperparathyroidism and increased production of PTH (Hasegawa et al. 2010). The ternary complex of klotho-FGF23-FGF receptor in distal convoluted tubules (DCTs) has been thought to be a prerequisite for the exertion of FGF23 effects (Kurosu et al. 2006), and, indeed, initial FGF23-mediated signaling occurs in DCTs (Farrow et al. 2009). However, it remains undetermined how FGF23-mediated signaling in DCTs leads to the regulation of NaPi-IIa and NaPi-IIc in PTCs. It may be possible that FGF23 has a direct action on PTCs (Huang and Moe 2011).

\subsubsection{Klotho}

Klotho was first identified as an aging suppressor gene product (Kuro-o et al. 1997). It is a single-pass transmembrane protein expressed predominantly in the kidney, intensely in DCTs and to a lesser extent in PTCs and parathyroid gland (Kuro-o 2011). Klotho-/- and Fgf23-/- mice show very similar phenotypes such as premature aging and abnormal mineral metabolism (Kuro-o 2011). As mentioned above, klotho acts with FGF receptor as a coreceptor in the binding of FGF23 in DCTs for phosphate and vitamin $\mathrm{D}_{3}$ regulation (Kurosu et al. 2006). The Klotho-FGF23-FGF receptor complex in DCTs may produce putative paracrine factors on PTCs where phosphate transporters and enzymes for vitamin $\mathrm{D}_{3}$ regulation are located (Huang and Moe 2011). The extracellular domain of Klotho is also known to be cleaved from plasma membranes, secreted to the circulatoin and present in urine (Hu et al. 2011); this soluble klotho form may directly act on PTCs. Klotho was also found to act as a PTC-synthesized autocrine factor in the FGF23-independent inhibition of $\mathrm{NaPi}$-IIa function by B-glucuronidase-like enzymatic activity (Hu et al. 2011). Decreased Klotho expression in the kidney may be one of initial factors triggering dysregulation of various hormones involved in phosphate homeostasis and the development of secondary hyperparathyroidism in CKD (Kuro-o 2011).

\subsubsection{Vitamin $D_{3}$}

As mentioned above, megalin and cubilin take up the $25(\mathrm{OH}) \mathrm{D}_{3} / \mathrm{DBP}$ complex from glomerular filtrates (Nykjaer et al. 1999; Nykjaer et al. 2001; Leheste et al. 2003). In PTCs, $25(\mathrm{OH}) \mathrm{D}_{3}$ is dissociated from DBP and converted by $1 \alpha$-hydroxylase to the biologically active form $1,25(\mathrm{OH})_{2} \mathrm{D}_{3}$, which is released to peritubular capillaries. Therefore, dysfunction of these endocytic receptors is an important cause of deficiency of both $25(\mathrm{OH}) \mathrm{D}_{3}$ and 
$1,25(\mathrm{OH})_{2} \mathrm{D}_{3}$ in CKD. The activation of vitamin $\mathrm{D}_{3}$ is also upregulated by PTH and downregulated by FGF23 (Shimada et al. 2004). Vitamin $\mathrm{D}_{3}$ deficiency develops very early in the course of CKD, especially in diabetic nephropathy, and is associated with the development of CVD or mortality in patients at the predialysis stage (Mehrotra et al. 2009).

\subsubsection{Other hormones}

Dopamine mediates renal phosphate excretion, which is affected by the function of renalase (Weinman et al. 2011). Chronic infusion of angiotensin II into rats was demonstrated to increase the expression of NaPi-IIa in PTC brush border membranes by posttranscriptional mechanisms (Xu et al. 2004). This increase of NaPi-Ila may be associated with an angiotensin II-mediated decrease in the expression of megalin that plays a role in endocytosis and the degradation of NaPi-IIa (Bachmann et al. 2004). Insulin may also be involved in regulating sodium-dependent phosphate transporters (Kunkler et al. 1991; Li et al. 1996). Glucocorticoids inhibit phosphate uptake in primary cultured rabbit PTCs via both nongenomic and genomic mechanisms (Park, Taub, and Han 2001). In addition, estrogen causes the PTH-independent downregulation of NaPi-IIa in PTCs (Faroqui et al. 2008).

\section{Conclusion}

There are a variety of hormonal actions and interactions involved in the regulation of important PTC functions such as receptor-mediated endocytosis and the reabsorption of sodium and phosphate. The impaired counterbalance of these hormones is likely to be associated with the development and/or progression of CKD. Elucidation of the mechanisms of such hormonal actions and interactions would therefore be of great benefit in the future development of novel therapeutic strategies for CKD.

\section{Acknowledgment}

This work was supported by a Grant-in-Aid for Scientific Research from the Ministry of Education, Science, and Culture of Japan (21591023).

\section{References}

Aminoff, M., J. E. Carter, R. B. Chadwick, C. Johnson, R. Grasbeck, M. A. Abdelaal, H. Broch, L. B. Jenner, P. J. Verroust, S. K. Moestrup, A. de la Chapelle, and R. Krahe. 1999. Mutations in CUBN, encoding the intrinsic factor-vitamin B12 receptor, cubilin, cause hereditary megaloblastic anaemia 1. Nat Genet 21 (3):309-13.

Bachmann, S., U. Schlichting, B. Geist, K. Mutig, T. Petsch, D. Bacic, C. A. Wagner, B. Kaissling, J. Biber, H. Murer, and T. E. Willnow. 2004. Kidney-specific inactivation of the megalin gene impairs trafficking of renal inorganic sodium phosphate cotransporter (NaPi-IIa). J Am Soc Nephrol 15 (4):892-900.

Bacic, D., M. Lehir, J. Biber, B. Kaissling, H. Murer, and C. A. Wagner. 2006. The renal $\mathrm{Na}+$ /phosphate cotransporter NaPi-IIa is internalized via the receptor-mediated endocytic route in response to parathyroid hormone. Kidney Int 69 (3):495-503.

Bailey, C. J., J. L. Gross, A. Pieters, A. Bastien, and J. F. List. 2010. Effect of dapagliflozin in patients with type 2 diabetes who have inadequate glycaemic control with metformin: a randomised, double-blind, placebo-controlled trial. Lancet 375 (9733):2223-33. 
Baum, M. 1987. Insulin stimulates volume absorption in the rabbit proximal convoluted tubule. J Clin Invest 79 (4):1104-9.

Bergwitz, C., N. M. Roslin, M. Tieder, J. C. Loredo-Osti, M. Bastepe, H. Abu-Zahra, D. Frappier, K. Burkett, T. O. Carpenter, D. Anderson, M. Garabedian, I. Sermet, T. M. Fujiwara, K. Morgan, H. S. Tenenhouse, and H. Juppner. 2006. SLC34A3 mutations in patients with hereditary hypophosphatemic rickets with hypercalciuria predict a key role for the sodium-phosphate cotransporter NaPi-IIc in maintaining phosphate homeostasis. Am J Hum Genet 78 (2):179-92.

Biemesderfer, D., B. DeGray, and P. S. Aronson. 2001. Active (9.6 s) and inactive (21 s) oligomers of NHE3 in microdomains of the renal brush border. J Biol Chem 276 (13):10161-7.

Biemesderfer, D., T. Nagy, B. DeGray, and P. S. Aronson. 1999. Specific association of megalin and the $\mathrm{Na}+/ \mathrm{H}+$ exchanger isoform NHE3 in the proximal tubule. J Biol Chem 274 (25):17518-24.

Bobulescu, I. A., V. Dwarakanath, L. Zou, J. Zhang, M. Baum, and O. W. Moe. 2005. Glucocorticoids acutely increase cell surface $\mathrm{Na}+\mathrm{H}+$ exchanger-3 (NHE3) by activation of NHE3 exocytosis. Am J Physiol Renal Physiol 289 (4):F685-91.

Bobulescu, I. A., and O. W. Moe. 2009. Luminal $\mathrm{Na}(+) / \mathrm{H}(+)$ exchange in the proximal tubule. Pflugers Arch 458 (1):5-21.

Boger, C. A., M. H. Chen, A. Tin, M. Olden, A. Kottgen, I. H. Deboer, C. Fuchsberger, C. M. O'Seaghdha, C. Pattaro, A. Teumer, C. T. Liu, N. L. Glazer, M. Li, J. R. O'Connell, T. Tanaka, C. A. Peralta, Z. Kutalik, J. Luan, J. H. Zhao, S. J. Hwang, E. Akylbekova, H. Kramer, P. van der Harst, A. V. Smith, K. Lohman, M. de Andrade, C. Hayward, B. Kollerits, A. Tonjes, T. Aspelund, E. Ingelsson, G. Eiriksdottir, L. J. Launer, T. B. Harris, A. R. Shuldiner, B. D. Mitchell, D. E. Arking, N. Franceschini, E. Boerwinkle, J. Egan, D. Hernandez, M. Reilly, R. R. Townsend, T. Lumley, D. S. Siscovick, B. M. Psaty, B. Kestenbaum, T. Haritunians, S. Bergmann, P. Vollenweider, G. Waeber, V. Mooser, D. Waterworth, A. D. Johnson, J. C. Florez, J. B. Meigs, X. Lu, S. T. Turner, E. J. Atkinson, T. S. Leak, K. Aasarod, F. Skorpen, A. C. Syvanen, T. Illig, J. Baumert, W. Koenig, B. K. Kramer, O. Devuyst, J. C. Mychaleckyj, C. Minelli, S. J. Bakker, L. Kedenko, B. Paulweber, S. Coassin, K. Endlich, H. K. Kroemer, R. Biffar, S. Stracke, H. Volzke, M. Stumvoll, R. Magi, H. Campbell, V. Vitart, N. D. Hastie, V. Gudnason, S. L. Kardia, Y. Liu, O. Polasek, G. Curhan, F. Kronenberg, I. Prokopenko, I. Rudan, J. Arnlov, S. Hallan, G. Navis, A. Parsa, L. Ferrucci, J. Coresh, M. G. Shlipak, S. B. Bull, A. D. Paterson, H. E. Wichmann, N. J. Wareham, R. J. Loos, J. I. Rotter, P. P. Pramstaller, L. A. Cupples, J. S. Beckmann, Q. Yang, I. M. Heid, R. Rettig, A. W. Dreisbach, M. Bochud, C. S. Fox, and W. H. Kao. 2011. CUBN Is a Gene Locus for Albuminuria. J Am Soc Nephrol. 22(3): 555-70

Brands, M. W., D. A. Hildebrandt, H. L. Mizelle, and J. E. Hall. 1991. Sustained hyperinsulinemia increases arterial pressure in conscious rats. Am J Physiol $2604 \mathrm{Pt}$ 2):R764-8.

Cabezas, F., J. Lagos, C. Cespedes, C. P. Vio, M. Bronfman, and M. P. Marzolo. 2011. Megalin/LRP2 expression is induced by peroxisome proliferator-activated receptor -alpha and -gamma: implications for PPARs' roles in renal function. PLoS One 6 (2):e16794. 
Carraro-Lacroix, L. R., G. Malnic, and A. C. Girardi. 2009. Regulation of Na+/H+ exchanger NHE3 by glucagon-like peptide 1 receptor agonist exendin-4 in renal proximal tubule cells. Am J Physiol Renal Physiol 297 (6):F1647-55.

Christensen, E. I., P. J. Verroust, and R. Nielsen. 2009. Receptor-mediated endocytosis in renal proximal tubule. Pflugers Arch.

Coudroy, G., J. Gburek, R. Kozyraki, M. Madsen, G. Trugnan, S. K. Moestrup, P. J. Verroust, and M. Maurice. 2005. Contribution of cubilin and amnionless to processing and membrane targeting of cubilin-amnionless complex. J Am Soc Nephrol 16 (8):2330-7.

Desir, G. V. 2011. Role of renalase in the regulation of blood pressure and the renal dopamine system. Curr Opin Nephrol Hypertens 20 (1):31-6.

Drumm, K., T. R. Kress, B. Gassner, A. W. Krug, and M. Gekle. 2006. Aldosterone stimulates activity and surface expression of NHE3 in human primary proximal tubule epithelial cells (RPTEC). Cell Physiol Biochem 17 (1-2):21-8.

Fan, Y. Y., M. Kohno, H. Hitomi, K. Kitada, Y. Fujisawa, J. Yatabe, M. Yatabe, R. A. Felder, H. Ohsaki, K. Rafiq, S. J. Sherajee, T. Noma, A. Nishiyama, and D. Nakano. 2011. Aldosterone/Mineralocorticoid receptor stimulation induces cellular senescence in the kidney. Endocrinology 152 (2):680-8.

Faroqui, S., M. Levi, M. Soleimani, and H. Amlal. 2008. Estrogen downregulates the proximal tubule type IIa sodium phosphate cotransporter causing phosphate wasting and hypophosphatemia. Kidney Int 73 (10):1141-50.

Farrow, E. G., S. I. Davis, L. J. Summers, and K. E. White. 2009. Initial FGF23-mediated signaling occurs in the distal convoluted tubule. J Am Soc Nephrol 20 (5):955-60.

Fuster, D. G., I. A. Bobulescu, J. Zhang, J. Wade, and O. W. Moe. 2007. Characterization of the regulation of renal $\mathrm{Na}+/ \mathrm{H}+$ exchanger NHE3 by insulin. Am J Physiol Renal Physiol 292 (2):F577-85.

Fyfe, J. C., M. Madsen, P. Hojrup, E. I. Christensen, S. M. Tanner, A. de la Chapelle, Q. He, and S. K. Moestrup. 2004. The functional cobalamin (vitamin B12)-intrinsic factor receptor is a novel complex of cubilin and amnionless. Blood 103 (5):1573-9.

Gans, R. O., L. vd Toorn, H. J. Bilo, J. J. Nauta, R. J. Heine, and A. J. Donker. 1991. Renal and cardiovascular effects of exogenous insulin in healthy volunteers. Clin Sci (Lond) 80 (3):219-25.

Gattineni, J., C. Bates, K. Twombley, V. Dwarakanath, M. L. Robinson, R. Goetz, M. Mohammadi, and M. Baum. 2009. FGF23 decreases renal NaPi-2a and NaPi-2c expression and induces hypophosphatemia in vivo predominantly via FGF receptor 1. Am J Physiol Renal Physiol 297 (2):F282-91.

Gonzalez-Villalobos, R., R. B. Klassen, P. L. Allen, K. Johanson, C. B. Baker, H. Kobori, L. G. Navar, and T. G. Hammond. 2006. Megalin binds and internalizes angiotensin-(17). Am J Physiol Renal Physiol 290 (5):F1270-5.

Gonzalez-Villalobos, R., R. B. Klassen, P. L. Allen, L. G. Navar, and T. G. Hammond. 2005. Megalin binds and internalizes angiotensin II. Am J Physiol Renal Physiol 288 (2):F420-7.

Good, D. W., T. George, and B. A. Watts, 3rd. 2006. Nongenomic regulation by aldosterone of the epithelial NHE3 $\mathrm{Na}(+) / \mathrm{H}(+)$ exchanger. Am J Physiol Cell Physiol 290 (3):C757-63.

Gutzwiller, J. P., S. Tschopp, A. Bock, C. E. Zehnder, A. R. Huber, M. Kreyenbuehl, H. Gutmann, J. Drewe, C. Henzen, B. Goeke, and C. Beglinger. 2004. Glucagon-like peptide 1 induces natriuresis in healthy subjects and in insulin-resistant obese men. J Clin Endocrinol Metab 89 (6):3055-61.

Hasegawa, H., N. Nagano, I. Urakawa, Y. Yamazaki, K. Iijima, T. Fujita, T. Yamashita, S. Fukumoto, and T. Shimada. 2010. Direct evidence for a causative role of FGF23 in 
the abnormal renal phosphate handling and vitamin $\mathrm{D}$ metabolism in rats with early-stage chronic kidney disease. Kidney Int 78 (10):975-80.

Hernando, N., S. M. Gisler, S. Pribanic, N. Deliot, P. Capuano, C. A. Wagner, O. W. Moe, J. Biber, and H. Murer. 2005. NaPi-IIa and interacting partners. J Physiol 567 (Pt 1):21-6.

Hirata, K., S. Kume, S. Araki, M. Sakaguchi, M. Chin-Kanasaki, K. Isshiki, T. Sugimoto, A. Nishiyama, D. Koya, M. Haneda, A. Kashiwagi, and T. Uzu. 2009. Exendin-4 has an anti-hypertensive effect in salt-sensitive mice model. Biochem Biophys Res Commun 380 (1):44-9.

Hong, C. Y., K. Hughes, K. S. Chia, V. Ng, and S. L. Ling. 2003. Urinary alpha1microglobulin as a marker of nephropathy in type 2 diabetic Asian subjects in Singapore. Diabetes Care 26 (2):338-42.

Hosojima, M., H. Sato, K. Yamamoto, R. Kaseda, T. Soma, A. Kobayashi, A. Suzuki, H. Kabasawa, A. Takeyama, K. Ikuyama, N. Iino, A. Nishiyama, T. J. Thekkumkara, T. Takeda, Y. Suzuki, F. Gejyo, and A. Saito. 2009. Regulation of megalin expression in cultured proximal tubule cells by angiotensin II type 1A receptor- and insulinmediated signaling cross talk. Endocrinology 150 (2):871-8.

$\mathrm{Hu}, \mathrm{M}$. C., M. Shi, J. Zhang, H. Quinones, C. Griffith, M. Kuro-o, and O. W. Moe. 2011. Klotho deficiency causes vascular calcification in chronic kidney disease. J Am Soc Nephrol 22 (1):124-36.

Huang, C. L., and O. W. Moe. 2011. Klotho: a novel regulator of calcium and phosphorus homeostasis. Pflugers Arch.

Ibarra, F., S. Crambert, A. C. Eklof, A. Lundquist, P. Hansell, and U. Holtback. 2005. Prolactin, a natriuretic hormone, interacting with the renal dopamine system. Kidney Int 68 (4):1700-7.

Kalantry, S., S. Manning, O. Haub, C. Tomihara-Newberger, H. G. Lee, J. Fangman, C. M. Disteche, K. Manova, and E. Lacy. 2001. The amnionless gene, essential for mouse gastrulation, encodes a visceral-endoderm-specific protein with an extracellular cysteine-rich domain. Nat Genet 27 (4):412-6.

Kestenbaum, B., J. N. Sampson, K. D. Rudser, D. J. Patterson, S. L. Seliger, B. Young, D. J. Sherrard, and D. L. Andress. 2005. Serum phosphate levels and mortality risk among people with chronic kidney disease. J Am Soc Nephrol 16 (2):520-8.

Klisic, J., M. C. Hu, V. Nief, L. Reyes, D. Fuster, O. W. Moe, and P. M. Ambuhl. 2002. Insulin activates $\mathrm{Na}(+) / \mathrm{H}(+)$ exchanger 3: biphasic response and glucocorticoid dependence. Am J Physiol Renal Physiol 283 (3):F532-9.

Klonoff, D. C., J. B. Buse, L. L. Nielsen, X. Guan, C. L. Bowlus, J. H. Holcombe, M. E. Wintle, and D. G. Maggs. 2008. Exenatide effects on diabetes, obesity, cardiovascular risk factors and hepatic biomarkers in patients with type 2 diabetes treated for at least 3 years. Curr Med Res Opin 24 (1):275-86.

Kobori, H., M. Nangaku, L. G. Navar, and A. Nishiyama. 2007. The intrarenal reninangiotensin system: from physiology to the pathobiology of hypertension and kidney disease. Pharmacol Rev 59 (3):251-87.

Kozyraki, R., J. Fyfe, P. J. Verroust, C. Jacobsen, A. Dautry-Varsat, J. Gburek, T. E. Willnow, E. I. Christensen, and S. K. Moestrup. 2001. Megalin-dependent cubilin-mediated endocytosis is a major pathway for the apical uptake of transferrin in polarized epithelia. Proc Natl Acad Sci U S A 98 (22):12491-6.

Kunkler, K. J., L. M. Everett, D. K. Breedlove, and S. A. Kempson. 1991. Insulin stimulates sodium-dependent phosphate transport by osteoblast-like cells. Am J Physiol 260 (5 Pt 1):E751-5. 
Kuro-o, M., Y. Matsumura, H. Aizawa, H. Kawaguchi, T. Suga, T. Utsugi, Y. Ohyama, M. Kurabayashi, T. Kaname, E. Kume, H. Iwasaki, A. Iida, T. Shiraki-Iida, S. Nishikawa, R. Nagai, and Y. I. Nabeshima. 1997. Mutation of the mouse klotho gene leads to a syndrome resembling ageing. Nature 390 (6655):45-51.

Kuro-o. M. 2011. Phosphate and Klotho. Kidney Int 79 (S121):S20-S23.

Kurosu, H., Y. Ogawa, M. Miyoshi, M. Yamamoto, A. Nandi, K. P. Rosenblatt, M. G. Baum, S. Schiavi, M. C. Hu, O. W. Moe, and M. Kuro-o. 2006. Regulation of fibroblast growth factor-23 signaling by klotho. J Biol Chem 281 (10):6120-3.

Leheste, J. R., F. Melsen, M. Wellner, P. Jansen, U. Schlichting, I. Renner-Muller, T. T. Andreassen, E. Wolf, S. Bachmann, A. Nykjaer, and T. E. Willnow. 2003. Hypocalcemia and osteopathy in mice with kidney-specific megalin gene defect. Faseb J 17 (2):247-9.

Li, H., P. Ren, M. Onwochei, R. J. Ruch, and Z. Xie. 1996. Regulation of rat Na+/Pi cotransporter-1 gene expression: the roles of glucose and insulin. Am J Physiol 271 (6 Pt 1):E1021-8.

Li, X. C., J. L. Cook, I. Rubera, M. Tauc, F. Zhang, and J. L. Zhuo. 2011. Intrarenal transfer of an intracellular cyan fluorescent fusion of angiotensin II selectively in proximal tubules increases blood pressure in rats and mice. Am J Physiol Renal Physiol.

List, J. F., and J. M. Whaley. 2011. Glucose dynamics and mechanistic implications of SGLT2 inhibitors in animals and humans. Kidney Int 79 Suppl 120:S20-7.

Liu, S., J. Zhou, W. Tang, X. Jiang, D. W. Rowe, and L. D. Quarles. 2006. Pathogenic role of Fgf23 in Hyp mice. Am J Physiol Endocrinol Metab 291 (1):E38-49.

Lorenz-Depiereux, B., A. Benet-Pages, G. Eckstein, Y. Tenenbaum-Rakover, J. Wagenstaller, D. Tiosano, R. Gershoni-Baruch, N. Albers, P. Lichtner, D. Schnabel, Z. Hochberg, and T. M. Strom. 2006. Hereditary hypophosphatemic rickets with hypercalciuria is caused by mutations in the sodium-phosphate cotransporter gene SLC34A3. Am J Hum Genet 78 (2):193-201.

Mandon, B., E. Siga, D. Chabardes, D. Firsov, N. Roinel, and C. De Rouffignac. 1993. Insulin stimulates $\mathrm{Na}+, \mathrm{Cl}-, \mathrm{Ca} 2+$, and $\mathrm{Mg} 2+$ transports in TAL of mouse nephron: crosspotentiation with AVP. Am J Physiol 265 (3 Pt 2):F361-9.

Mangos, G. J., J. A. Whitworth, P. M. Williamson, and J. J. Kelly. 2003. Glucocorticoids and the kidney. Nephrology (Carlton) 8 (6):267-73.

Mehrotra, R., D. A. Kermah, I. B. Salusky, M. S. Wolf, R. I. Thadhani, Y. W. Chiu, D. Martins, S. G. Adler, and K. C. Norris. 2009. Chronic kidney disease, hypovitaminosis D, and mortality in the United States. Kidney Int 76 (9):977-83.

Murer, H., I. Forster, and J. Biber. 2004. The sodium phosphate cotransporter family SLC34. Pflugers Arch 447 (5):763-7.

Navar, L. G., M. C. Prieto, R. Satou, and H. Kobori. 2011. Intrarenal angiotensin II and its contribution to the genesis of chronic hypertension. Curr Opin Pharmacol.

Nykjaer, A., D. Dragun, D. Walther, H. Vorum, C. Jacobsen, J. Herz, F. Melsen, E. I. Christensen, and T. E. Willnow. 1999. An endocytic pathway essential for renal uptake and activation of the steroid 25-(OH) vitamin D3. Cell 96 (4):507-15.

Nykjaer, A., J. C. Fyfe, R. Kozyraki, J. R. Leheste, C. Jacobsen, M. S. Nielsen, P. J. Verroust, M. Aminoff, A. de la Chapelle, S. K. Moestrup, R. Ray, J. Gliemann, T. E. Willnow, and E. I. Christensen. 2001. Cubilin dysfunction causes abnormal metabolism of the steroid hormone 25(OH) vitamin D(3). Proc Natl Acad Sci U S A 98 (24):13895-900. 
Ohkido, I., H. Segawa, R. Yanagida, M. Nakamura, and K. Miyamoto. 2003. Cloning, gene structure and dietary regulation of the type-IIc Na/Pi cotransporter in the mouse kidney. Pflugers Arch 446 (1):106-15.

Park, S., M. Taub, and H. Han. 2001. Regulation of phosphate uptake in primary cultured rabbit renal proximal tubule cells by glucocorticoids: evidence for nongenomic as well as genomic mechanisms. Endocrinology 142 (2):710-20.

Picard, N., P. Capuano, G. Stange, M. Mihailova, B. Kaissling, H. Murer, J. Biber, and C. A. Wagner. 2010. Acute parathyroid hormone differentially regulates renal brush border membrane phosphate cotransporters. Pflugers Arch 460 (3):677-87.

Pohl, M., H. Kaminski, H. Castrop, M. Bader, N. Himmerkus, M. Bleich, S. Bachmann, and F. Theilig. 2010. Intrarenal renin angiotensin system revisited: role of megalindependent endocytosis along the proximal nephron. J Biol Chem 285 (53):41935-46.

Pontuch, P., T. Jensen, T. Deckert, P. Ondrejka, and M. Mikulecky. 1992. Urinary excretion of retinol-binding protein in type 1 (insulin-dependent) diabetic patients with microalbuminuria and clinical diabetic nephropathy. Acta Diabetol 28 (3-4):206-10.

Ravera, S., L. V. Virkki, H. Murer, and I. C. Forster. 2007. Deciphering PiT transport kinetics and substrate specificity using electrophysiology and flux measurements. Am J Physiol Cell Physiol 293 (2):C606-20.

Russo, L. M., E. del Re, D. Brown, and H. Y. Lin. 2007. Evidence for a role of transforming growth factor (TGF)-beta1 in the induction of postglomerular albuminuria in diabetic nephropathy: amelioration by soluble TGF-beta type II receptor. Diabetes 56 (2):380-8.

Saito, A., R. Kaseda, M. Hosojima, and H. Sato. 2010. Proximal tubule cell hypothesis for cardiorenal syndrome in diabetes. Int J Nephrol 2011:957164.

Saito, A., H. Sato, N. Iino, and T. Takeda. 2010. Molecular mechanisms of receptor-mediated endocytosis in the renal proximal tubular epithelium. J Biomed Biotechnol 2010:403272.

Schlatter, P., C. Beglinger, J. Drewe, and H. Gutmann. 2007. Glucagon-like peptide 1 receptor expression in primary porcine proximal tubular cells. Regul Pept 141 (1-3):120-8.

Seetharam, B., E. I. Christensen, S. K. Moestrup, T. G. Hammond, and P. J. Verroust. 1997. Identification of rat yolk sac target protein of teratogenic antibodies, gp280, as intrinsic factor-cobalamin receptor. J Clin Invest 99 (10):2317-22.

Seetharam, B., J. S. Levine, M. Ramasamy, and D. H. Alpers. 1988. Purification, properties, and immunochemical localization of a receptor for intrinsic factor-cobalamin complex in the rat kidney. J Biol Chem 263 (9):4443-9.

Segawa, H., I. Kaneko, A. Takahashi, M. Kuwahata, M. Ito, I. Ohkido, S. Tatsumi, and K. Miyamoto. 2002. Growth-related renal type II Na/Pi cotransporter. J Biol Chem 277 (22):19665-72.

Segawa, H., S. Yamanaka, A. Onitsuka, Y. Tomoe, M. Kuwahata, M. Ito, Y. Taketani, and K. Miyamoto. 2007. Parathyroid hormone-dependent endocytosis of renal type IIc NaPi cotransporter. Am J Physiol Renal Physiol 292 (1):F395-403.

Shimada, T., M. Kakitani, Y. Yamazaki, H. Hasegawa, Y. Takeuchi, T. Fujita, S. Fukumoto, K. Tomizuka, and T. Yamashita. 2004. Targeted ablation of Fgf23 demonstrates an essential physiological role of FGF23 in phosphate and vitamin D metabolism. J Clin Invest 113 (4):561-8. 
Tabatabai, N. M., M. Sharma, S. S. Blumenthal, and D. H. Petering. 2009. Enhanced expressions of sodium-glucose cotransporters in the kidneys of diabetic Zucker rats. Diabetes Res Clin Pract 83 (1):e27-30.

Takahashi, N., O. Ito, and K. Abe. 1996. Tubular effects of insulin. Hypertens Res 19 Suppl 1:S41-5.

Takeyama, A., H. Sato, T. Soma-Nagae, H. Kabasawa, A. Suzuki, K. Yamamoto-Kabasawa, M. Hosojima, R. Kaneko, F. Higuchi, R. Kaseda, S. Ogasawara, I. Narita, and A. Saito. 2011. Megalin is downregulated via LPS-TNF-alpha-ERK1/2 signaling pathway in proximal tubule cells. Biochem Biophys Res Commun.

Tanner, S. M., M. Aminoff, F. A. Wright, S. Liyanarachchi, M. Kuronen, A. Saarinen, O. Massika, H. Mandel, H. Broch, and A. de la Chapelle. 2003. Amnionless, essential for mouse gastrulation, is mutated in recessive hereditary megaloblastic anemia. Nat Genet 33 (3):426-9.

Thomson, S. C., V. Vallon, and R. C. Blantz. 2004. Kidney function in early diabetes: the tubular hypothesis of glomerular filtration. Am J Physiol Renal Physiol 286 (1):F8-15.

Tiwari, S., V. K. Halagappa, S. Riazi, X. Hu, and C. A. Ecelbarger. 2007. Reduced expression of insulin receptors in the kidneys of insulin-resistant rats. J Am Soc Nephrol 18 (10):2661-71.

Tiwari, S., N. Sharma, P. S. Gill, P. Igarashi, C. R. Kahn, J. B. Wade, and C. M. Ecelbarger. 2008. Impaired sodium excretion and increased blood pressure in mice with targeted deletion of renal epithelial insulin receptor. Proc Natl Acad Sci U S A 105 (17):6469-74.

Tojo, A., M. L. Onozato, H. Ha, H. Kurihara, T. Sakai, A. Goto, T. Fujita, and H. Endou. 2001. Reduced albumin reabsorption in the proximal tubule of early-stage diabetic rats. Histochem Cell Biol 116 (3):269-76.

Tojo, A., M. L. Onozato, H. Kurihara, T. Sakai, A. Goto, and T. Fujita. 2003. Angiotensin II blockade restores albumin reabsorption in the proximal tubules of diabetic rats. Hypertens Res 26 (5):413-9.

Vilsboll, T., M. Zdravkovic, T. Le-Thi, T. Krarup, O. Schmitz, J. P. Courreges, R. Verhoeven, I. Buganova, and S. Madsbad. 2007. Liraglutide, a long-acting human glucagon-like peptide-1 analog, given as monotherapy significantly improves glycemic control and lowers body weight without risk of hypoglycemia in patients with type 2 diabetes. Diabetes Care 30 (6):1608-10.

Wang, D., H. Zhang, F. Lang, and C. C. Yun. 2007. Acute activation of NHE3 by dexamethasone correlates with activation of SGK1 and requires a functional glucocorticoid receptor. Am J Physiol Cell Physiol 292 (1):C396-404.

Weinman, E. J., R. Biswas, D. Steplock, P. Wang, Y. S. Lau, G. V. Desir, and S. Shenolikar. 2011. Increased renal dopamine and the acute renal adaptation to a high phosphate diet. Am J Physiol Renal Physiol.

Xu, J., G. Li, P. Wang, H. Velazquez, X. Yao, Y. Li, Y. Wu, A. Peixoto, S. Crowley, and G. V. Desir. 2005. Renalase is a novel, soluble monoamine oxidase that regulates cardiac function and blood pressure. J Clin Invest 115 (5):1275-80.

Xu, L., M. P. Dixit, R. Chen, N. M. Dixit, J. F. Collins, and F. K. Ghishan. 2004. Effects of angiotensin II on NaPi-IIa co-transporter expression and activity in rat renal cortex. Biochim Biophys Acta 1667 (2):114-21.

Yammani, R. R., S. Seetharam, and B. Seetharam. 2001. Identification and characterization of two distinct ligand binding regions of cubilin. J Biol Chem 276 (48):44777-84.

Yu, M., C. Moreno, K. M. Hoagland, A. Dahly, K. Ditter, M. Mistry, and R. J. Roman. 2003. Antihypertensive effect of glucagon-like peptide 1 in Dahl salt-sensitive rats. $J$ Hypertens 21 (6):1125-35. 


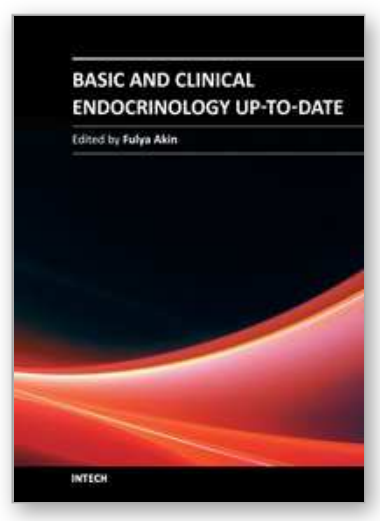

\author{
Basic and Clinical Endocrinology Up-to-Date \\ Edited by Dr. Fulya Akin
}

ISBN 978-953-307-340-8

Hard cover, 350 pages

Publisher InTech

Published online 17, October, 2011

Published in print edition October, 2011

This book provides the most up-to-date information on the basic and clinical aspects of endocrinology. It offers both researchers and clinicians experts, gold-standard analysis of endocrine research and translation into the treatment of diseases such as insulinoma, endocrine disease in pregnancy and steroid induced osteoporosis. Investigates both the endocrine functions of the kidneys and how the kidney acts as a target for hormones from other organ systems. Presents a uniquely comprehensive look at all aspects of endocrine changes in pregnancy and cardiovascular effects of androgens.

\title{
How to reference
}

In order to correctly reference this scholarly work, feel free to copy and paste the following:

Akihiko Saito, Michihiro Hosojima and Hiroyoshi Sato (2011). Hormonal Actions and Interactions in Proximal Tubule Cells Associated with the Development of Chronic Kidney Disease, Basic and Clinical Endocrinology Up-to-Date, Dr. Fulya Akin (Ed.), ISBN: 978-953-307-340-8, InTech, Available from:

http://www.intechopen.com/books/basic-and-clinical-endocrinology-up-to-date/hormonal-actions-andinteractions-in-proximal-tubule-cells-associated-with-the-development-of-chroni

\section{INTECH}

open science | open minds

\section{InTech Europe}

University Campus STeP Ri

Slavka Krautzeka 83/A

51000 Rijeka, Croatia

Phone: +385 (51) 770447

Fax: +385 (51) 686166

www.intechopen.com

\section{InTech China}

Unit 405, Office Block, Hotel Equatorial Shanghai

No.65, Yan An Road (West), Shanghai, 200040, China

中国上海市延安西路65号上海国际贵都大饭店办公楼405单元

Phone: +86-21-62489820

Fax: $+86-21-62489821$ 
(C) 2011 The Author(s). Licensee IntechOpen. This is an open access article distributed under the terms of the Creative Commons Attribution 3.0 License, which permits unrestricted use, distribution, and reproduction in any medium, provided the original work is properly cited. 